\title{
THE EARLY BYZANTINE WEIGHTS FROM KUNSZENTMÁRTON, HUNGARY
}

\author{
CHRIS ENTWISTLE \\ Late Roman and Byzantine Collections \\ Department of Britain, Europe and Prehistory \\ The British Museum \\ Great Russell Street, London WC1B 3DG, United Kingdom \\ centwistle@britishmuseum.org
}

\begin{abstract}
This paper re-analyses the Early Byzantine metal and glass weights excavated at Kunszenmárton in the early 1930s. It offers the latest comparanda for the weights, an up-to-date bibliography for non-specialists, and an appendix of finds of Byzantine weights from central and south-eastern European contexts.

Keywords: Metrology, commodity weight, coinage weight, metal, glass, prefect, eparch, Early Byzantine
\end{abstract}

Finds of Byzantine weights beyond the confines of the empire's borders are, unlike coins, a relative rarity. Perhaps the most important discovery to date of a discrete assemblage of both commodity and coinage weights is that from the site of Kunszentmárton in Hungary, published in 1933 by Dezső Csallány. ${ }^{1}$ Excavations there revealed the grave of an Avar goldsmith with numerous dies for belt-fittings and strap-ends, tools including, inter alia, punches, hammers and pliers, together with scales and nine Byzantine weights. Five of these weights were of copper-alloy, four of glass.

\section{METROLOGY}

The metrological system employed throughout the Late Roman and Early Byzantine periods was a duodecimal one. ${ }^{2}$ The linchpin of this system was the Late Roman pound or litra, derived from the Roman pound. The litra was divided into twelve ounces, the ounce into multiples of the scripulum, which at $1.13 \mathrm{~g}$ was the smallest unit of the libral system (see Table 1). The litra was also divisible into 72 solidi: the solidus, later known as the nomisma, was the standard gold coin introduced by Constantine the Great in 309 , which was to retain its weight and fineness well into the tenth century. The solidus weighed 24 siliquae or carats, the siliqua being a naturally occurring unit, the average weight of the seed of the carob tree or St John's wort (Ceratonia siliqua), and now taken to be the equivalent of $0.189 \mathrm{~g}$ (see Table 1). Imperial legislation of the fourth century records that 72 solidi were struck to the pound. The theoretical weight of the solidus is generally taken by numismatists to be $4.54 \mathrm{~g}$ (or 4.55 g), thus giving a theoretical weight for the Late Roman/Early Byzantine pound of circa $327.45 \mathrm{~g}$. Such exactitude in matters of ancient metrology necessitates scepticism. Not only is it clear that the weight of the solidus fluctuated, but it is also extremely unlikely that an administrative system of sufficient complexity existed to impose a standard weight system throughout the vast expanse of the Late Roman empire. In a recent study of Byzantine metrology,

${ }^{1}$ See, Csallány 1933.
${ }^{2}$ For a comprehensive study of Byzantine metrology see, SCHILBACH 1970. 
Table 1: Late Roman and Byzantine metrological system

\begin{tabular}{|c|l|l|}
\hline 1 pound $=12$ ounces $=12$ solidi $=288$ scruples & $=1,728$ carats (keratia) & \\
\hline 1 ounce $=6$ solidi $=24$ scruples & $=144$ carats & \\
\hline 1 solidus $=4$ scruples & $=24$ carats & $=6$ carats \\
\hline 1 scruple (or gramma) & & 1 carat (or siliqua) \\
\hline
\end{tabular}

based on the weights of surviving coins, E. Schilbach proposed the following figures for the pound during the Late Roman and Early Byzantine eras: about $324 \mathrm{~g}$ from the fourth to the sixth century, $322 \mathrm{~g}$ in the sixth and seventh centuries, and $320 \mathrm{~g}$ from the seventh to the ninth century. ${ }^{3}$ Alternative figures of $326.34 \mathrm{~g}, 324 \mathrm{~g}$ and $322.56 \mathrm{~g}$, among others, have also been suggested by other metrologists as a figure for the Late Roman pound. ${ }^{4}$ On the evidence of those surviving weights preserved in the collections of numerous European and American museums, these figures should be treated with some caution. The British Museum, for example, possesses thirteen $1 \mathrm{lb}$ weights dating from between the third and seventh centuries weighing as follows: $323.76 \mathrm{~g}, 323.71 \mathrm{~g}, 322.53 \mathrm{~g}, 322.10 \mathrm{~g}$, $321.80 \mathrm{~g}, 321.71 \mathrm{~g}, 319.90 \mathrm{~g}, 318.11 \mathrm{~g}, 315.92 \mathrm{~g}, 311.20 \mathrm{~g}, 309.14 \mathrm{~g}, 301.15 \mathrm{~g}$ and $300.63 \mathrm{~g}$. Their deviation from any of the theoretical figures noted above cannot simply be explained because these weights have lost their inlays or are damaged in other respects (indeed corrosion products can sometimes add to the weight). The metrological evidence supplied by surviving Late Roman weights not only suggests that extreme caution should be used in ascribing highly accurate weights to specific units, but also strongly suggests the existence of local weight standards. That these existed in the Roman period at least is proved by a lead weight from Banias in Israel which is inscribed in Greek: 'A third of the local libra'. ${ }^{5}$ It is also implied in some instances in the surviving sources: thus Symmachus, describing the occasion of a gift by the Roman senate of 1,600 lbs of gold on the occasion of Valentinian II's decennalia, alludes to the pound's weight according to urban i.e. Roman standards. ${ }^{6}$ However, for convenience's sake, the figure of $327.45 \mathrm{~g}$ for the pound is retained, whilst acknowledging that this is an approximate figure.

The principal symbol for the pound (litra) was the Greek letter lambda $(\Lambda)$; that for the ounce (ounggia) either an omicron surmounted by an upsilon or $\Gamma$ with an omicron in the angles of the letter. It is often asserted in the literature that the use of the $\mathrm{O} / \mathrm{V}$ abbreviation is much earlier than the $\Gamma / \mathrm{O}$ sign. Given that the $\Gamma / O$ as an abbreviation for the ounce is known as early the first century AD from a Neronic Egyptian weight, this sharp chronological division seems dubious. ${ }^{7}$ The principal abbreviations employed on Late Roman commodity and coinage weights are as follows:

\section{ADMINISTRATION}

The administration of 'official' weights and measures devolved to a number of imperial and civic personnel. For much of the fourth century the supervision of weights was administered by the aediles or agoronomoi of each city. Gradually, however, these officials were superseded by others. A law of Julian the Apostate's, preserved in the Codex Theodosianus, appoints an official known as the zygostates (literally 'weigher') to each city to control the issuance of weights and settle any disputes between buyer and seller. By the sixth century the responsibility for weights and measures had shifted to other officials. Caput 15 of Novel 128 of Justinian, dated 545, states: 'we command those who exact public taxes to use just weights and measures so that they may not injure our tax-payers in this respect. If, nevertheless, tax-payers do feel themselves injured, whether in matters of weighing, or in those of measuring, they have the permission to receive the weights and measures of commodities from the Most Glorious Prefects, and the weights of gold, silver and other metals from the Most Glorious Comes Sacrarum Largitionum of the time'. In reality this division of responsibilities does not appear to have been strictly adhered to. Thus the prefect of Constantinople is known to have been issuing coinage weights as early as the 560s, as exemplified by four weights issued by the eparch Flavios Zimarchos: a 72 nomisma example once in the Kircheriano Museum, Rome,

\footnotetext{
${ }^{3}$ SchilbaCH 1970, 166-168.

${ }^{4}$ For a recent discussion with bibliography see, GRIERSONMAYs 1992, 29-30.
}

\footnotetext{
${ }^{5}$ KUSHNIR-STEIN 1995.

${ }^{6}$ Symmachus, Relationes XIII.

${ }^{7}$ LANG 1959.
} 
Table 2: Denominational marks for the pound and ounce

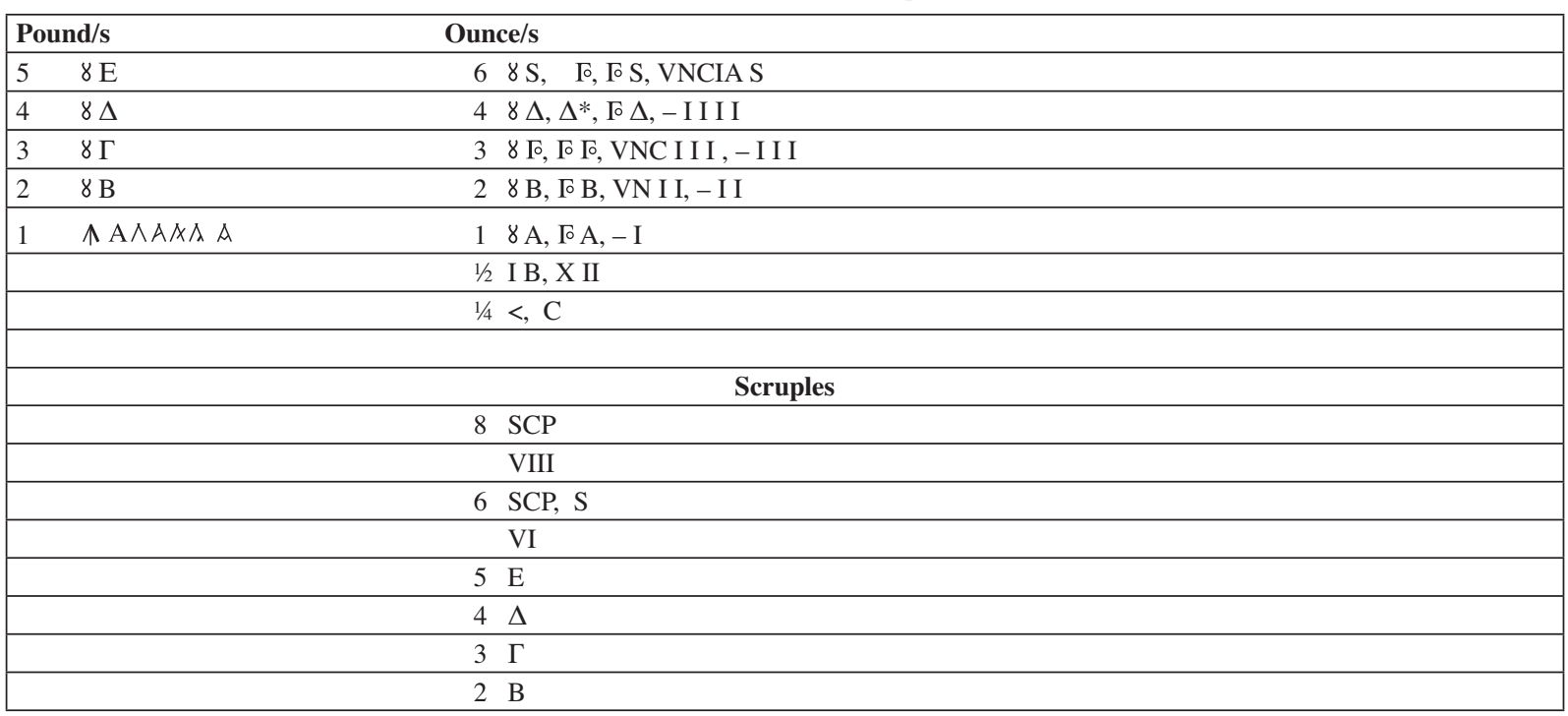

a 36 nomisma weight in a British private collection, an 18 nomisma weight in the Cabinet des Médailles, Paris, and finally, a 3 nomisma weight in the Benaki Museum, Athens. ${ }^{8}$ Steelyard balances were also issued by the eparch as evidenced by an example from Bulgaria inscribed in Greek 'in the time of Gerontios, the most magnificent eparch of the city'. ${ }^{9}$ The prefect of the capital, and probably the prefects of the major provincial cities, were also responsible for the emission of glass coin and commodity weights during the sixth and first half of the seventh centuries. ${ }^{10}$ In reality other officials unmentioned in imperial legislation also issued weights, and recorded titles include those of the comes rei privatae, comes, anthypatos and ephoros.

Of particular relevance to the Kunszentmárton assemblage is a further group of inscribed weights which appear to be entirely western Mediterranean or North African in origin. These may be divided roughly into two groups: weights issued by viri clarissimi or viri laudibili, and those issued by various prefects and proconsuls. The former category either have a Latin monogram, or more rarely an inscription, on one side and the letters VC on the other; or an abbreviated personal name in Latin on one side and the letters VL on the reverse. The names of seven viri laudibili have been recorded: Silvanus, Secundius, Laurentius, Frumentius, Raginarius, Purpurius and Respectus. ${ }^{11}$ It is to the second category - those inscribed with the names of prefects/consuls - that the inscribed weight (cat. no. 4) from Kunszentmárton belongs. D. Csallány, probably due to the corrosion and patination on the obverse, read only the reverse inscription - as PREF (pref[ecti]). In fact, the obverse side is also inscribed in Latin: ATANASI (Atanasi; Athanasius). This is best compared with a weight, probably from Carthage, inscribed ATANI | SIPREF on one side and PETRI | PROC on the other. ${ }^{12}$ Both these individuals are probably identifiable. The most likely candidates are an Athanasius who was praetorian prefect of Italy 539-542 and praetorian prefect of Africa 545-548, and a Petrus who was magister officiorum 539-565, patricius by 542 and possibly consul as early as $539 .{ }^{13}$

If these two Athanasiuses are one and the same, then this weight would give the Kunszentmárton assemblage a terminus post quem of around 540 at the earliest.

\footnotetext{
${ }^{8}$ GARRUCCI 1846; DieUdONNÉ 1931, 11-22.

${ }^{9}$ STEFAN 1965, 141-145.

${ }^{10}$ FEISSEL 1986.

${ }^{11}$ BUTTREY-BRUCE HitCHNER 1978, 155-156 for the bibliographic references.
}

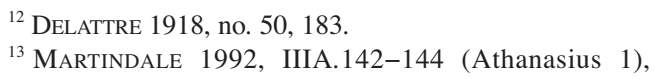

${ }^{13}$ Martindale 1992, IIIA.142-144 (Athanasius 1), 
Table 3: Denominational marks for the solidus/nomisma

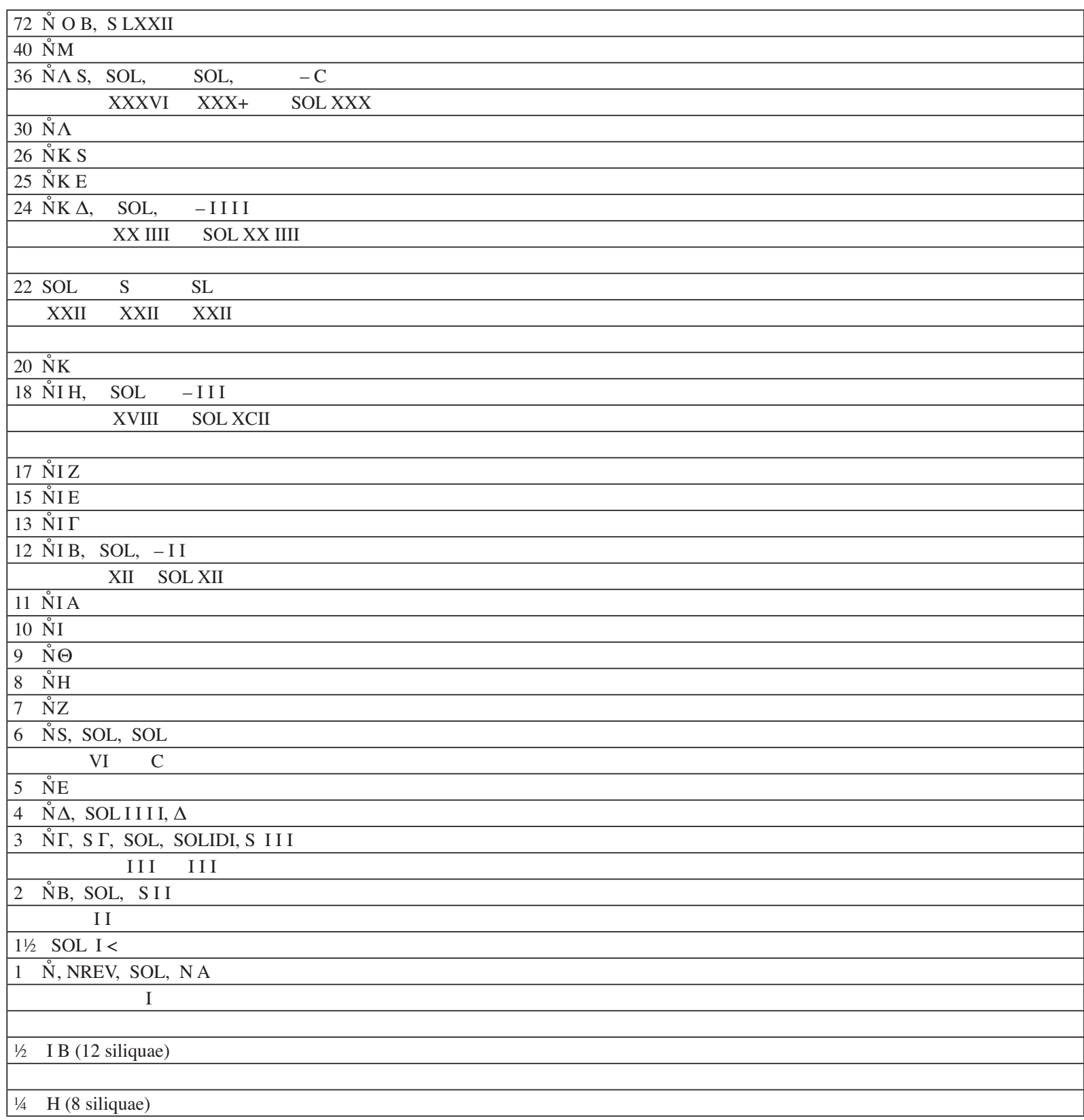


Three materials were commonly employed in the manufacture of Byzantine commodity and coinage weights: bronze, glass and lead. In very rare instances gold and silver was also used. ${ }^{14}$ Copper-alloy weights take three main forms: a flattened sphere doubly truncated, a square or a disk; occasionally octagonal or polygonal examples have survived (Fig. 1). The very limited archaeological and epigraphic evidence suggests the following tenuous typological chronology. From the beginning of the third to the end of the fifth century weights in the form of a truncated sphere were the dominant type. These were derived from earlier Roman lead and stone examples and nearly all bear the omicron/upsilon $(\mathrm{O} / \mathrm{V})$ abbreviation for the ounce. Although the use of the gamma/omicron $(\Gamma \mathrm{O})$ as an uncial abbreviation is known as early as the first century, it does not become the standard abbreviation until its appearance on square weights during the course of the fourth century. The square type appears to have been the dominant form until the latter half of the sixth when the discoid type gradually superseded it. Finds from such sites as Yassi Ada, ${ }^{15}$ Beth Shean, ${ }^{16}$ Mafraq, ${ }^{17}$ Amorium ${ }^{18}$ and San Vincenzo al Volturno, ${ }^{19}$ suggest that the discoid type was predominant from the seventh through to the early ninth century. If the suggested chronology at Corinth is correct - this is the only site to have produced quantities of commodity weights supposedly dating from the Middle Byzantine period - then discoid weights were still being produced as late as the twelfth century. ${ }^{20}$ Within this broad chronological framework there are undoubtedly variations. Recent excavations in Rome suggest that both spheroidal and square weights continued side by side well into the seventh century with discoid weights not making an appearance there until the eighth century. ${ }^{21}$ These discoid weights are of considerable interest as they clearly belong to the Late Roman metrological system, but have abandoned the denominational formulae for signifying pounds, ounces, solidi etc., for purely geometric ornament composed of engraved lines and punched dots. Similar weights have also been found in Corinth and more recently at the site of the Middle Byzantine shipwreck at Serce Limani. ${ }^{22}$ Excavations there unearthed fifteen bronze weights representing 11/2 pounds (1), 1 pound (2) 6 ounces (3) 3 ounces (2), 2 ounces (4) and 1 ounce (3). All are discoid and, like the similar weights from Rome and Corinth, bear no denominations.

Of the few thousand odd Byzantine weights which have survived most fall into the category of "miscellaneous": that is they are simply marked with their relevant denomination and perhaps a subsidiary decorative motif such as a cross. It is possible, however, to isolate and roughly date certain iconographic types. The most common in the Early Byzantine period is the 'cross within wreath' type. This takes two forms: a wreath enclosing a prominent Latin cross flanked by the denominational mark, or a wreath enclosing a cross above the denominational mark. These two designs are commonly found on square weights dating from the fifth and sixth centuries and are found from Holland in the north to Portugal in the west, Nubia in the south and the Crimea in the east. Other distinctive types include weights with architectural decoration - either a single arch enclosing a cross and the denomination, or a facade composed of two triangular arches and one rounded arch enclosing the same - or 'imperial' weights, that is weights decorated with one or more imperial figures. The standard format for this type depicts two imperial busts, nimbed, diademed and wearing paludamenta fastened by stylised fibulae on the right shoulder, within a wreath. More elaborate examples show standing emperors with shields, spears or bows engaged in abbreviated hunting scenes or juxtaposed with other figures such as Tyches or Victories. Such weights, more than any other, are clearly vehicles of imperial propaganda and were mainly issued in the late fourth and early fifth centuries at a time when the empire was split for administrative purposes. The only other series of weights exclusively decorated with imperial figures are exagia solidi. These were issued specifically as coin weights, seemingly to check the weights of the solidus and semissis. Introduced by Julian, most are to be dated to the late fourth or early fifth centuries, although examples dating from the reigns of Marcian and Leo are known. ${ }^{23}$ It is probably no coincidence that as the last series of exagia solidi were being struck that glass weights seem to make their first appearance.

${ }^{14}$ For a gold semissis-weight of Marcian, see: Frank STERNBERG 1995, lot 543, 70. For a $1 \mathrm{oz}$ silver weight dating from the reign of Theodora, see: BUCKTON 1994, no. 164.

${ }^{15}$ BASS-DOORNINCK 1982.

${ }^{16}$ The weights from Beth Shean in Israel are as yet unpublished. But all of those from seventh century contexts are discoid.

${ }^{17}$ Humbert 1986, 20, pl. 7.

${ }^{18}$ LightFOOT 2008, 379-87.
${ }^{19}$ A $20 z$ discoid weight (Small find no. 1393) which was found in an early ninth century context in a workshop at the southern end of the site: MitCHELl 2000, 461, fig. 317.

${ }^{20}$ DAVIDSON 1952, nos 1595, 1602, 1605-1606, 209-210, pls. 94-95.

${ }^{21}$ Arena et al. 2001, 340-44, 544-546.

${ }^{22}$ VAN DOORNINCK 2002

${ }^{23}$ ELMER 1942. 

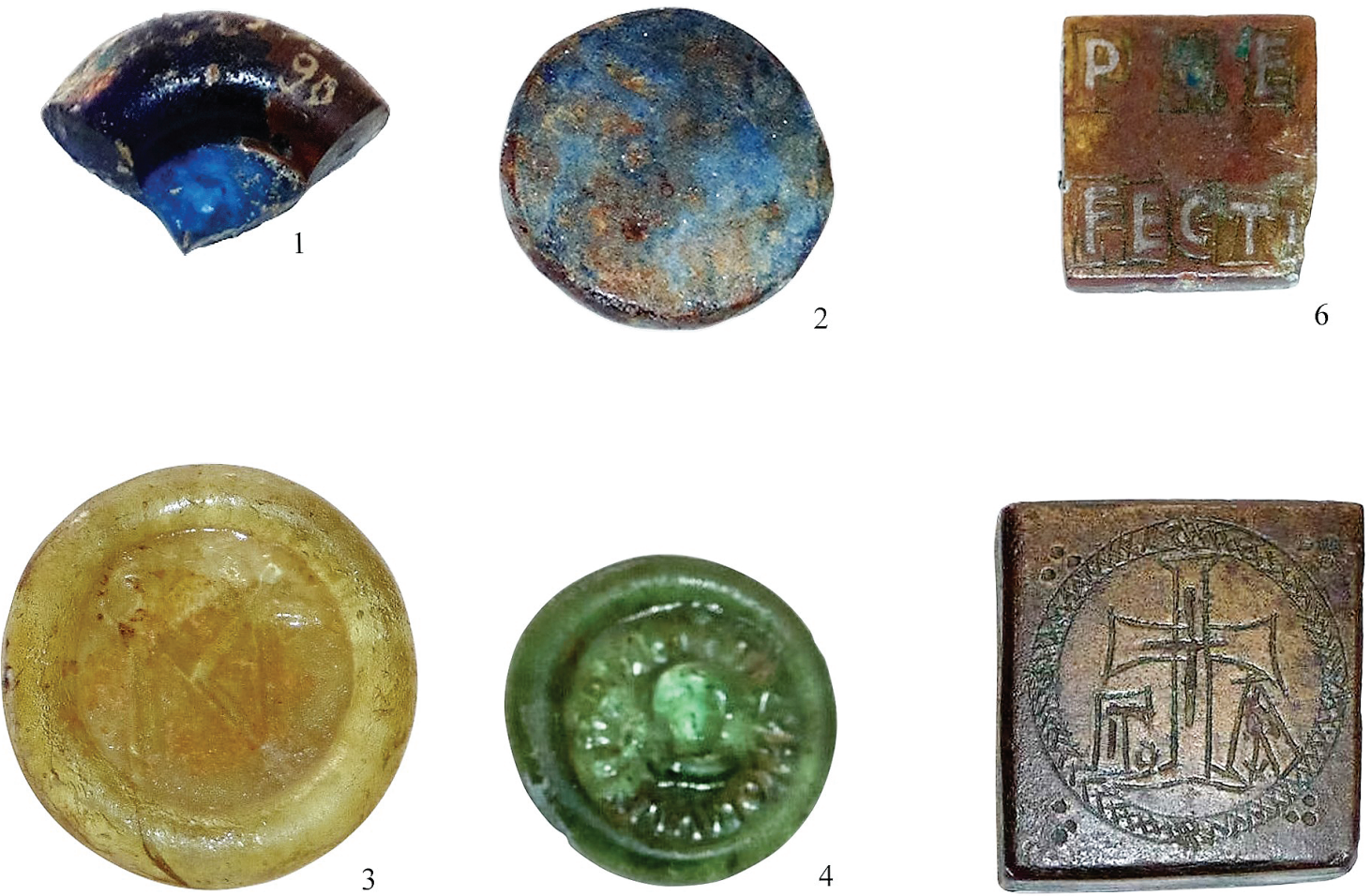

7
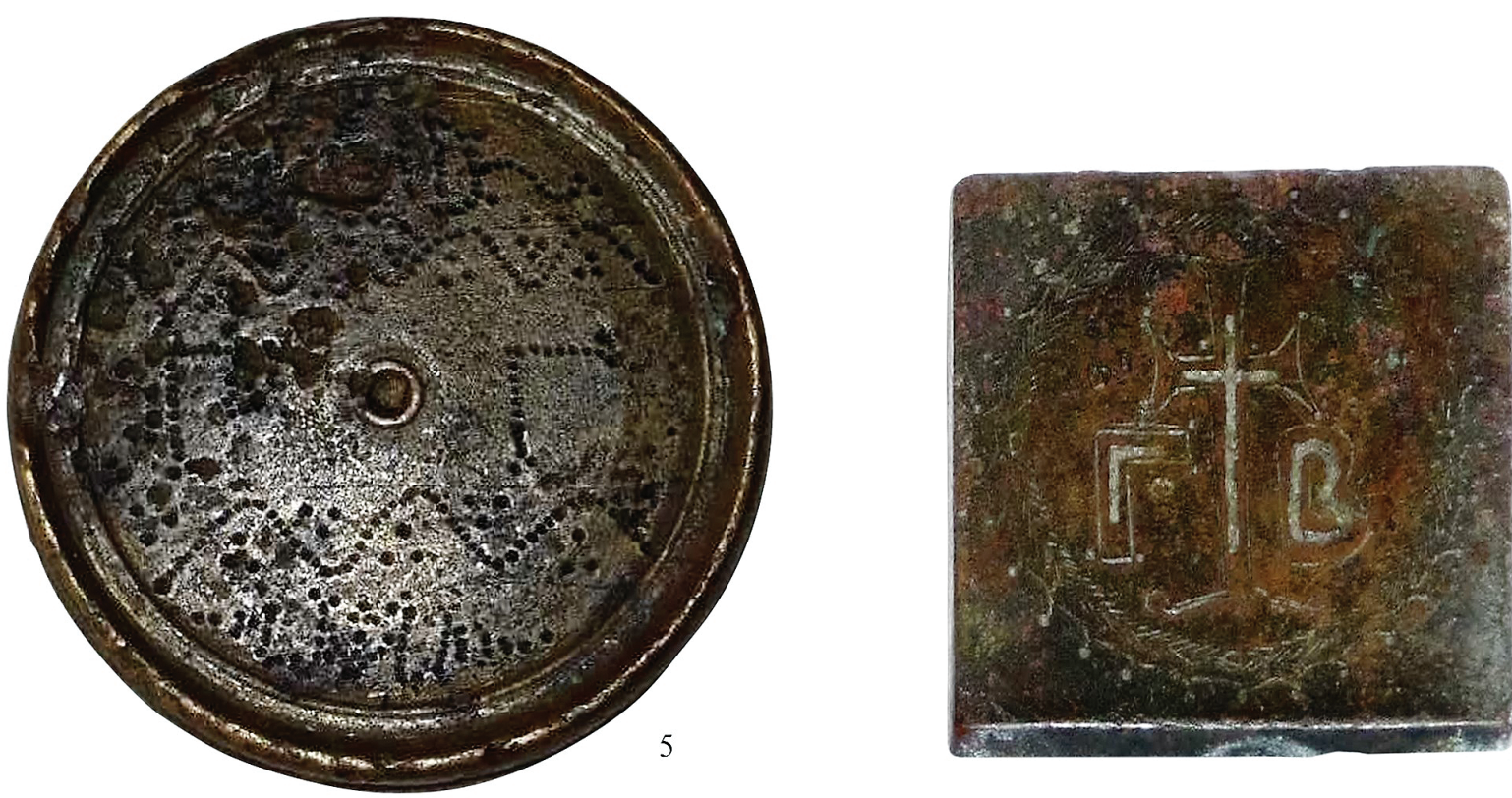

8

Fig 1. Early Byzantine weights of the Early Avar Period grave assemblage from Kunszentmárton 


\section{GLASS WEIGHTS}

Early Byzantine glass weights are generally in the form of small disks stamped with either monograms (cat. no. 7) or busts with accompanying Greek inscriptions (cat. no. 6) relating to the relevant issuing authorities - the prefects of Constantinople and other major urban centres. ${ }^{24}$ Although a wide range of translucent colours are known, various shades of blue, blue-green and yellowy-brown tend to be predominant. Glass as a material for weights had certain advantages. Unlike lead or bronze it was not prone to oxidation or corrosion, and attempts to alter its weight were more readily detectable. The method of manufacturing glass weights - some, if not all, were produced by pouring a blob of glass onto an iron plate and then stamping it with an iron die - had an additional advantage: those weights significantly above or below the relevant mean could be re-melted and re-used. The precise function of these glass disks has, nevertheless, occasionally been questioned. The reason for this is that they do not always correspond exactly to known coin denominations. This counter-argument may be rejected on a number of grounds. First, I do not believe that Byzantine weights whether of metal or glass were ever intended to be highly accurate measures of the gold and silver coins which those designated as coinage weights, at least, were intended to weigh. This reservation is supported by the rough and ready design of most contemporary coin balances, whether of metal or bone. Most of these weights were intended as rule-of-thumb weights for checking the tolerance above or below which most coins would or not be accepted in everyday commercial transactions. Second, a recent statistical analysis of over five hundred glass weights suggests that the majority of them were used to weigh the solidus/ nomisma (theoretical weight $4.54 \mathrm{~g}$ ) and its divisions the semissis (theoretical weight $2.27 \mathrm{~g}$ ) and tremissis (theoretical weight $1.55 \mathrm{~g}$ ). ${ }^{25} \mathrm{~A}$ very rare group of glass weights stamped with denominational marks illustrate without any doubt that they were made to weigh not only light-weight solidi and multiples of the solidus, but also multiples and divisions of the pound. ${ }^{26}$

Over twenty different iconographic types of glass weights have been identified. These can be conveniently compressed into the following eight categories: weights stamped with a box monogram; with a cruciform monogram; with a central monogram enclosed by an inscription; with one or more imperial busts sometimes juxtaposed with a monogram or a bust of an eparch or Christ; with a bust of an eparch with identifying inscription; with a bust of an eparch without inscription; with a denominational mark; and finally, weights with debased monograms or busts, sometimes referred to as 'Arabo-Byzantine'. Of these categories the most typical are those simply stamped with a box or cruciform monogram. So many different types have survived that it suggests that if the rough chronology for glass weights is correct - most are dated to the sixth and first half of the seventh century - then the monograms must refer not only to the prefects of Constantinople but to the eparchs of the major cities of the empire. The eventual disappearance of glass weights during the course of the seventh century can probably be ascribed to both the contraction of the economy during this period and the disruption of the administrative apparatus involved in their manufacture and distribution following the loss of such key provinces as Syria and Egypt to the Persians and Arabs.

To conclude. The weights from Kunszentmárton are, with the exception of the example inscribed with Athanasius' name, of little diagnostic relevance to a precise dating of the assemblage. The juxtaposition of both square and discoid Byzantine metal weights is scarcely unparalleled: in this instance, it probably points to a date in the first half of the seventh century, perhaps with a slight emphasis on the period circa AD 600-625. The importance of the find lies more in its contribution towards the argument about the function of Byzantine glass weights. As with the similar finds from Jutas and Pókaszepetk it is hard to think of an alternative function for these glass disks. Not only do their weights correspond to known coin types, but they are also found in conjunction with copper-alloy weights, balances and scale pans, objects whose metrological function is not in question. The fact that three out of the four only known examples of glass and bronze weights found in conjunction with weighing equipment are to be found in Hungary obviously lends itself to a host of interpretations: most belong to the realms of the sociology and economy of Avar culture an area in which I am most certainly not competent to theorise. Finds of Byzantine weights - both of metal and glass - in central and south-eastern Europe are either so rare or lacking detailed archaeological contexts as to make any remarks as to their importance to the economy of those areas in the sixth and

${ }^{24}$ For a selection of glass weight types see: MONNERET DE VILLARD 1922. For their composition and distribution see: ENTWISTLEMEEK 2015; AsOLATI 2016.

${ }^{25}$ LEESE forthcoming.
${ }^{26}$ The largest example known to me is an unpublished two pound weight in the Rockefeller Museum, Jerusalem. Further unpublished examples for weighing three nomisma are likewise in Israel and the Petrie Museum, University College, London. 
seventh centuries superfluous. It will only be when the chronology of Early Byzantine weights is understood more widely throughout the whole of the eastern Mediterranean and its hinterlands that anything remotely resembling generalities as to the significance of their typology and distribution will become relevant. Nevertheless, I hope that this brief updating of some aspects of Byzantine metrology is not without interest to non-specialist colleagues in south-eastern Europe.

\section{CATALOGUE}

1. Copper-alloy weight, square; engraved on the front with a double herring-bone wreath enclosing a prominent cross flanked by the denominational mark $\Gamma \mathrm{B}(2 \mathrm{oz})$, both the mark and the cross originally inlaid with silver.

Cf. Papadopoulos-Kerameus 1880, no. 7 (52.92 g ), 78; KubitscheK 1892, nos 6 (52.69 g), 7 (54.25 g) and 10 (50.58 g), 89-90; Pernice 1894, no. 845 (51.21 g); Monceaux 1916, no. 1 (53 g), 200-201; Petrie 1926, nos 5339 (53.41 g), 5380 (54.94 g) and 5401 (55.63 g); DieudonNÉ 1931, no. 37 (57 g); EMERY 1938, no. 859; ČUistova 1962, nos. 143 (53 g), 145 (50 g) and 148 (52.9 g); Ross 1962, no. 81 (51.65 g); DÜRR 1964, nos 42 (51.83 g), 43 (53.98 g), $44(54.53 \mathrm{~g}), 50$ (51.67 g), $51(51.09 \mathrm{~g}), 52(53.51 \mathrm{~g}), 53(53.41 \mathrm{~g}), 55(53.59 \mathrm{~g})$ and $57(53.19$ g); MANns 1976, no. 12 (50 g); Münz Zentrum 1977, no. 2037 (54.13 g); Christie's 1980, no. 242; QEDAR 1981, nos 131 (53.65 g) and 134 (52.52 g); Houben 1982, nos 40 (53.5 g), 41 (53 g), 42 (52 g) and 43 (52 g); Qedar 1983, no. 5134 (54.25 g); Christie's 1983a, no. 64 (50 g); Christie's 1983b, no. 34; VASILOPOUlou 1983, no. 19 (51.21 g); Heinz-w. Müller 1988, no. 543 (50.3 g); KNIFIC-SAGAdin 1991, no. 66 (47.31 g); ARENA et al. 2001, no. II.4.124 (52.6g); MANGANARo 2001, 69, nos 7 (53.89g) and 11; TeKIN-ÇELIK 2013, no. 276 (48.40g); CAMPAGNOLO-WeBER 2015, no. 97 (53.70g), TeKIN 2015, nos 93 (55.50g), 94 (52.70g), 95 (53.20g), 96 (53.45g) and 97 (52.25g); ENTWISTLE 2017, nos 213-231.

2. Copper-alloy weight, square; engraved on the front with a herring-bone wreath enclosing a prominent cross flanked by the denominational mark $\Gamma \mathrm{A}(1 \mathrm{oz})$, both the mark and the cross originally inlaid with silver; between each corner and the wreath, four groups of three punched dots. 23 x $22 \mathrm{~mm}$; WT $27.50 \mathrm{~g}$.

Cf. Delattre 1883, no. 2 (27.70 g), 55; Delattre 1899, no. 7 (27.70 g), 60; Delattre 1900, no. 11 (27.5 g); Strzygowski 1904, no. 7152 (24 g); Decloedt 1914, no. A 1 (26.30 g); Holwerda 1924, 18; Čuistova 1962, no. 125 (26.10 g); DürR 1964, nos 72 (26.75 g), 74 (25.99 g), 77 (26.29 g), 80 (25.68 g), 99 (26.60 g), 100 (26.87 g), 101 (27.22 g) and 103 (25.82 g); BREUER-ALENUs-LeCERF 1965, no. A (26.12 g), 104; MAnNs 1976, no. 17 (25 g); QedAr 1978, no. 102 (26.62 g); QedAr 1979, nos 4165 (26.36 g) and 4166 (26.17 g); Christie's 1980, no. 53 (26 g); Qedar 1981, no. 142 (24.36 g); Houben 1982, no. 46 (26 g); Gurt-Pellicer 1983, no. 28 (26.4 g), 184; Vasilopoulou 1983, no. 29 (23.97 g); Qedar 1983, no. 5139 (25.54 g); probably SAGui 1993, 416 (weight unknown); MANGANARo 2001, 69, no. 8 (26.90g); STIEGEMANN 2001, no. III.42 (27.1g); Papanikola-BakirtZi 2002, no. 32 (26.30 g); Holland 2009, nos 51 (26.8g) and 53 (26.4g); TeKin-ÇeliK 2013, nos $281(25.95 \mathrm{~g})$ and $282(26.16 \mathrm{~g})$; TEKIN 2015, nos $111(26.15 \mathrm{~g}), 112(25.90 \mathrm{~g}), 113(25.70 \mathrm{~g}), 114(26.60 \mathrm{~g})$ and $115(26.70 \mathrm{~g})$; ENTWISTLE 2017, nos 232-240.

3. Copper-alloy weight, square; deeply engraved on the face with $\mid$; multiple file marks on the reverse.

4. Copper-alloy weight, square; engraved on the face ATA I NASI, and on the base PRE I FECTI, both with remains of a corroded silver inlay; the bottom right-hand corner of the weight missing.

Cf. Delattre 1918, no. 50.

5. Copper-alloy weight, discoid; lathe-turned with prominent centring points and rims on face and base; punched with the denominational mark $\Gamma \Gamma(3 \mathrm{oz}$.); above and below the mark, two bands containing a wavy line motif with a pattern of three punched dots in each of its concavities; above and below each of the bands, further punched geometric ornament.

Cf. Dieudonné 1931, no. 34 (15 nomismata); ČUistova 1962, no. 112 and ManNs 1976, no. 13 (two 2 oz examples); DürR 1964, nos 143 and 313 for (12 nomismata and 1 oz); Gerasimov 1973, no. 12 (3 oz); Kondić-Popović 1977, no. 86 (6 nomisma); Bendall 1996, no. 114 (6 oz.); Hendin 2007, no. 376 (3 oz.); TeKIn 2015, nos 162 (6 oz.), nos 169 and 170 (3 oz.); ENTwistle 2017, nos 487, 489, 492 and 509 (6 $\mathrm{oz}, 3 \mathrm{oz}, 2 \mathrm{oz}$ and 12 nomismata).

6. Glass weight, discoid; stamped on the face with the bust of an eparch holding a mappa in his right hand and enclosed by the Greek

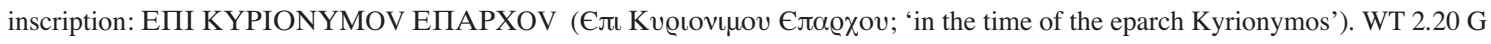

Cf. Jungfleisch 1932, nos M 4416 (4.46 g) and N 4262 (2.20 g); ZACOS-Veglery 1972, nos 2998a (4.32 g) and $2998 \mathrm{~b}$ (4.48 g); Vladimirova-Aladjova 2001, 42 (4.17g); Entwistle 2017, nos 724 (3.69g) and 725 (2.16g); Vikan no. B 44 (1.36 g); there is also an unpublished example in the American Numismatic Society Museum, New York (4.22 g).

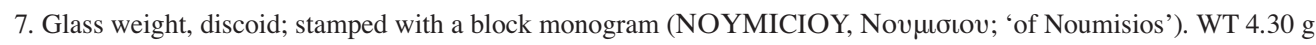


Cf. Tobias 2015, no. 720 (3.45g); Entwistle 2017, no. 617 (2.01g); ViKan nos 92 (3.94 g) and 93 (4.56 g) for two unpublished examples in the De Menil Collection, Houston; there is also an unpublished example in the American Numismatic Society Museum, New York $(4.46 \mathrm{~g})$. For a retrograde example of the monogram see: JUNGFLEISCH 1932, no. 31 (3.64 g).

The last two glass weights (nos 8-9) are either illegible or fragmentary.

\section{APPENDIX: FINDS OF BYZANTINE WEIGHTS IN CENTRAL AND SOUTH-EASTERN EUROPE}

\section{Albania}

1) Butrint. Bronze/square/1 nomisma.

2) Fenice. Bronze/square/2 oz/ 1oz/18 nomisma.

Austria

1) Carnuntum. Bronze/spheroidal $/ 1 \mathrm{lb} / 6 \mathrm{oz} / 3 \mathrm{oz} / 1 / 2 \mathrm{oz}$.

2) Enns. Bronze/spheroidal/1 lb/6 oz.

3) Hemmaburg. Bronze/discoid/5 nomisma; bronze/square/1 nomisma.

4) Salzburg. Bronze/spheroidal/6 oz.

5) Vienna. Bronze/spheroidal/6 oz.

Bosnia and Herzegovina

1) Narona (Metković - Vid). Bronze/octagonal/ $1 \mathrm{oz}$.

Bulgaria $^{27}$

1) Abritus. Bronze/square/1 nomisma. Bronze/discoid/8 siliqua. Coins converted to weights for semissis and tremissis.

2) Beroe-Augusta Traiana. Bronze/spheroidal/6 oz/1 oz; bronze/discoid/12 nomisma/2 nomisma; glass/busts/cruciform monogram.

3) Bistritsa. Bronze/square/1 nomisma.

4) Bluskovo (Varna district). Bronze/square/8 siliqua.

5) Dragoevo (Shumen district). Bronze/square/8 siliqua. Bronze/discoid/8 siliqua.

6) Dupniščenko. Bronze/spheroidal/6 oz.

7) Gabrovo. Bronze/spheroidal/6 oz/4oz; bronze/discoid/1 oz.

8) Hajdučka Vodenica. Bronze/square/1 oz/12 siliqua.

9) Montana. Glass weight.

10) Odărci. Bronze/discoid/2 nomisma.

11) Odessos (Varna). Glass/block monogram.

12) Padarsko (Kouroudjilari), near Plovdiv. Bronze/spheroidal/.

13) Parvomay. Bronze/spheroidal/3 oz, 2 oz.

14) Pernik. Bronze/square/1 nomisma; Glass/cruciform monogram (2)

15) Plovdiv. Bronze/square/6 oz.

16) Preslav (Shumen district). Glass/monogram. Bronze/square/8 siliqua.

17) Rjahovo. Bronze/square/6 nomisma/1 nomisma (2).

18) Roupki (near Stara Zagora). Glass/block monogram.

19) Sadovec. Glass/block monogram.

20) Silistra. Bronze/square/3 oz; bronze/square/1 nomisma (2); bronze/discoid/1 nomisma.

21) Stanata (Novi Pazar). Bronze/square/1 nomisma; bronze/discoid/2 nomisma.

22) Stara Zagora. Glass/ block monogram.

23) Tolbuhin. Bronze/discoid/2 nomisma.

24) Veliki Preslav. Bronze/discoid.

25) Venchan. Broze/square/1 nomisma.

26) Vojdova. Bronze/square/1 oz/3 solidi/1 nomisma (5); bronze/discoid/7 nomisma/2 nomisma

27) Zaldapa. Bronze/square/3 solidi/1 solidus.

Croatia

1) Pula. Bronze/spheroidal/1 lb.

2) Solin (Salona). Numerous bronze spheroidal weights; glass weights.

3) Split. Numerous bronze spheroidal, square and discoid weights; glass weights.

${ }^{27}$ See MiNČEV 2008 for a recent list of finds from northeast Bulgaria. CURTA-GĂNDILA 2011-2012 - a list of solidus. A solidus and semisses weight found in the Balkans. 
Germany

1) Bonn. Bronze/spheroidal/6 oz.

2) Heidelberg. Bronze/spheroidal/1 lb/6 oz.

3) Minheim. Bronze/square/6 oz.

4) Klepsau. Bronze/octagonal//2 nomisma.

5) Schwabsburg. Bronze/discoid/1oz.

6) Schwarzrheindorf. Bronze/square/12 keratia.

7) Singen. Bronze/square/5 nomisma.

8) Trier. Bronze/spheroidal/1 lb/6 oz/2 oz/1 oz/6 scruples. Bronze/square/6oz/1 nomisma. Bronze/exagia solidi (3).

9) Urach. Bronze/square/3 oz.

\section{Greece}

1) Aegina. Glass/block monogram.

2) Corinth. Numerous bronze and glass weights.

3) Crete. Glass/block monogram.

4) Delos. Bronze/octagonal/1 oz.

5) Erythres. Bronze/square/ 1 lb. Bronze/discoid/30 and 26, 2420 nomisma.

6) Kavala. Lead weight.

7) Megara. Bronze/square/1 lb.

6) Samos. Bronze/discoid/3 lbs.

7) Thessaloniki. Bronze/spheroidal/1 oz. Glass weight/monogram.

Hungary

1) Csákvár

2) Dunaújváros (Dunapentele). Bronze/spheroidal.

3) Gorsium (Tác). Bronze/spheroidal/4 oz and $3 \mathrm{oz}$.

4) Izsák. Bronze/3oz.

5) Jutas/Öskü. Bronze/square/6 nomisma. Glass weight (?). Balance/pans.

6) Kunszentmárton: see above.

7) Pókaszepetek. Bronze/discoid/1oz/2 nomisma. Glass weight/cruciform monogram. Balance/ pans.

Kosovo

1) Čečan. Bronze/square/1 oz.

2) Kamenica. Bronze/square/2 oz

2) Gornji Streoc. Bronze/square/1 nomisma.

Macedonia

1) Cučer. Bronze/square/1 nomisma.

2) Heraklea Lyncestis. Bronze/square/3 nomisma/3 solidi; bronze/discoid/2 nomisma.

3) Jegunovce. Bronze/octagonal/12 keratia.

4) Lopatica. Bronze/square/1 nomisma.

5) Lukovica. Bronze/square/2 oz.

6) Modrishte Bronze/square/1 nomisma

7) Pčinja. Bronze/square/1 nomisma.

8) Skachinci. Bronze/square/1 nomisma.

9) Sopot. Bronze/square/12 keratia.

10) Stobi. Bronze/spheroidal/2 oz/1 oz; bronze/square/3 nomisma; bronze/discoid/2 oz.

11) Sushitsa. Bronze/square/1 nomisma.

12) Teobo. Bronze/square/1 nomisma.

13) Zdunje. Bronze/square/8 keratia/.

Rumania

1) Adamclisi (Tropaeum Traiani). Bronze/discoid/5 nomisma. Glass/block monogram; glass weight/inscription.

2) Constanţa (Tomiş). Bronze/square/2 oz

3) Histria. Bronze/discoid/3 nomisma.

4) Izvoarele. Bronze/discoid/2 nomisma (2)

5) Mangalia (Callatis). Bronze/square/1nomisma.

6) Păcuiul lui Soare. Glass/box monogram/inscription. Bronze/coin balance.

7) Turda. Bronze/spheroidal. 
Serbia

1) Bela Palanka. Bronze/octagonal $/ 3$ oz.

1) Caričin Grad. Bronze/discoid/1 oz/; bronze/discoid/6/4/3/1 nomisma. Glass/monogram.

2) Prahovo. Bronze/square/1 nomisma (3), eight siliquae (2).

Slovenia

1) Orehek (near Stopiče). Bronze/square/2 oz.

2) Polhov Gradec Bronze/spheroidal/1lb/6 oz/4 oz/3 oz/2 oz/1 oz. Bronze/square/1 lb/6 oz

3) Svete Gore (Bizeljsko - Svete gore). Bronze/discoid/5 nomisma.

\section{REFERENCES}

ARENA et al. 2001

ASOLATI 2016

BASS-DOORNINCK 1982

BREUER-ALENUS-LECERF 1965

BUCKTON 1994

ButTREy-BRUCE HitCHNER 1978

CAmpagnolo-Weber 2015

Christie's 1980

Christie's $1983 \mathrm{a}$

Christie's 1983b

CSALLÁNY 1933

Čujstova 1962

CURTA-GĂNDILA 2011-2012

DAVIDSON 1952

DECLOEDT 1914

Delattre 1883

DELATTRE 1899

DELATTRE 1900

DelatTRe 1918

DiEUdonNÉ 1931

DÜRR 1964

ELMER 1942

EMERY 1938

ENTWISTLE 2008

ENTWISTLE 2017
= M. S. Arena et al. (ed.): Roma dall'Antichita al Medioevo Archeologia e Storia nel Museo Nazionale Romano Crypta Balbi. Rome 2001.

= M. Asolati: Trasparenze ponderali: contrappesi monetali di vetro nell'Anatolia bizantina. PCA. Post-Classical Archaeologies 6 (2016) 163-188.

$=$ G. BASS-F. H. van DOORnINCK Jr.: Yassi Ada. 1: A Seventh-Century Byzantine Shipwreck. College Station 1982.

= J. Breuer-J. Alenus-LeCERF: La boite à poids monétaires de Lutlommel. Archaeologia Belgica 86 (1965) 103-116.

= D. BuckTon (ed.): Byzantium: Treasures of Byzantine Art and Culture from British Collections. Exhibition catalogue. London 1994.

= T. V. ButTREY-R. BruCE HitchneR: The coins - 1976. In: Excavations at Carthage 1976 Conducted by the University of Michigan. 4. Ed.: J. H. Humphrey. Ann Arbor 1978.

= M. CAmpagnolo-K. Weber: Poids romano-byzantins et byzantins en alliage cuivreux. Collections du Musée d'art et d'histoire - Genève 4 = Collections byzantines du MAH - Genève. Geneva 2015.

$=$ Christie's. Fine Antiquities. Wednesday 26 November 1980, London.

= Christie's. Fine Antiquities. London Wednesday 13 July 1983, London.

= Christie's London. Fine Antiquities. Tuesday 13 and Wednesday 14 December 1983, London.

= D. CsAllÁNY: A kunszentmártoni avarkori ötvössír - Goldschmiedegrab aus der Awarenzeit von Kunszentmárton (Ungarn). Szentes 1933.

= L. I. Čusstova: Antičnye i srednevekovye vesovye sistemy, imevšie choždenie v severnom Pričernomor'e [Antique and early medieval weighting-systems circulating in the Northern Black Sea Region]. Archeologija i Istorija Bospora 2 (1962) 7-235.

= F. CURTA-A. GĂndILA: Moards and Hoarding Pottery in the Early Byzantine Balkans. Dumbarton Oaks Papers 65-66 (2011-2012) 45-112.

= G. R. DAVIDSON: Corinth. XII: The Minor Objects. Princeton 1952.

= A. Decloedt: Note sur des poids grecs et byzantins du Musée Biblique de Sainte-Anne. Revue Biblique 1 (1914) 549-555.

= A. L. Delattre: Poids antiques de bronze trouvés à Carthage et conservés au Musée de Saint-Louis. Bulletin de l'Académie d'Hippone 18 (1883) 53-58.

= A. L. Delattre: Musée Lavigerie de Saint-Louis de Carthage. Musées et collections archéologiques de l'Algérie et de la Tunisie, $3^{\text {rd }}$ ser. Paris 1899.

= A. L. Delattre: Poids de bronzes antiques. Revue Tunisienne 7 (1900) 411-426.

= A. L. Delattre: Poids byzantins trouvés la plupart à Carthage. Bulletin archéologique du Comité des Travaux historiques et scientifiques. Paris 1918.

= A. Dieudonné: Poids du bas-empire et byzantins des Collections Schlumberger et Froehner et de l'ancien fonds du Cabinet. Revue Numismatique 34 (1931) 11-22.

= N. DürR: Catalogue de la Collection Lucien Naville au Cabinet de Numismatique du Musée d'Art et d'Histoire de Genève. Genava 12 (1964) 1-42.

= G. ELMER: Marcianus korabeli solidus pénzsúly. [A Marcian's time solidus coin weight]. NK 41 (1942) 58-59.

= B. EMERY: The Royal Tombs of Ballana and Qustul. With chapters by L. P. Kirwan. Mission archéologique de Nubie, 1929-1934. Cairo 1938.

= C. ENTWISTLE: Late Roman and Byzantine weights and weighing equipment in the British Museum. In: E. Jeffreys-J. F. Haldon-R. Cormack: The Oxford Handbook of Byzantine Studies. Oxford-New York 2008, 38-47.

= C. EnTwistle: Catalogue of the Late Roman and Byzantine Weights and Weighing Equipment in the British Museum. London 2017 (forthcoming). 
ENTWISTLE-MEEK 2015

FEISSEL 1986

Frank Sternberg 1995

GARRUCCI 1846

GERASIMOV 1973

GuRT-PELLICER 1983

GRIERSON-MAYS 1992

Heinz-w. Müller 1988

HOLLAND 2009

HOLWERDA 1924

HOUBEN 1982

HUMBERT 1986

Jacques Schulman 1980

JUNGFLEISCH 1932

Kondić-PoPOVIĆ 1977

KNIFIC-SAGADIN 1991

KUBITSCHEK 1892

KUSHNIR-STEIN 1995

LANG 1959

LEESE forthcoming

LiGHTFOOT 2008

MANGANARO 2001

MANNS 1976

MARTINDAle 1992

MINČEV 2008

MitChell 2000

Monceaux 1916

Monneret DE VILlaRd 1922

Münz Zentrum 1977

PAPAdOPOULOS-KERAMEUS 1880

PAPANIKOLA-BAKIRTZI 2002

PERNICE 1894
= C. ENTwistLE-A. MEEK: Early Byzantine glass weights: aspects of function, typology and composition. British Museum Technical Research Bulletin 9 (2015) 1-14.

= D. FeISSEL: Le préfet de Constantinople, les poids-étalons et l'estampillage de l'argenterie au VI ${ }^{\mathrm{e}}$ et au VII ${ }^{\mathrm{e}}$ siècle. Revue Numismatique 28 (1986) 119-142.

= Frank STERnBerg: Antike Münzen... Auktion XXIX 30. und 31. Oktober 1995 in Zürich. Frank Sternberg AG - Zürich. Zürich 1995.

$=$ R. GarruCCI: Pesi antichi del Museo Kircheriano. Annali di Numismatica di Fiorelli 1 (1846) 201-211.

$=$ T. GeRAsimov: Rannovizantijski ekzegii ot Bălgariâ [Early Byzantine exagia in Bulgaria]. ArhSof 2 (1973) 54-58.

= J. P. GurT-J. Pellicer: Pesales antiguos del Museu de l'Orient Biblic de la Abadía de Montserrat. Numisma. Revista de la Sociedad Iberoamericana de Estudios Numismaticos 33 (1983) 177-190.

= P. GRIERSON-M. MAYs: Catalogue of Late Roman Coins in the Dumbarton Oaks Collection and in the Whittemore Collection. From Arcadius and Honorius to the Accession of Anastasius. Dumbarton Oaks 1992.

= Heinz-w. Müller: Auktion 58. 3.-4. Juni 1988. Antike-Neuzeit. Griechen. Römische Kaiserzeit. Antike Objekte....Heinz-W. Müller...Wermelskirchener Str. 46. 5650 Solingen 25, Solingen.

= L. Holland: Weights and Weight-Like Objects from Maritima Caesarea. Hadera 2009.

= J. H. Holwerda: De Franken in Nederland. OML 5 (1924) 1-50.

= G. M. M. Houben: Bronze Byzantine weights. OML 63 (1982) 133-143.

= J.-P. HuMBERT: El-Fedein. Mafraq, Jordanie. Rapport préliminaire de la campagne de fouilles 1986. Jerusalem 1986

= Jacques Schulman: List 218-October. Fixed Price List no. 32. Jacques Schulman B.V. Keizersgracht 448 Amsterdam-Holland, Amsterdam.

= M. JungFLEISCH: Les dénéraux et estampilles byzantins en verre de la Collection Froehner. Bulletin de l'Institut d'Egypte 14 (1932) 233-56.

= V. Kondić-V. Popović: Caričin Grad: Site fortifié dans l'Illyricum byzantin. Beograd 1977.

= T. KNIFIC-M. SAGAdin: Pismo brez pisave. Arheologija o prvih stoletjih krščanstva na Slovenskem [A Letter without Written Words. The Archaeology of the First Centuries of Christianity in Slovenia]. Ljubljana 1991.

= J. W. KubiTscheK: Gewichtsstücke aus Dalmatien. Archäologisch-Epigraphische Mitteilungen aus Österreich-Ungarn 13 (1892) 85-90.

= A. KushniR-Stein: Two inscribed weights from Banias. Israel Exploration Journal 45/1 (1995) 48-51.

= M. LANG: A Roman bronze weight from Egypt. American Numismatic Society Museum Notes 7 (1959) 91-93.

= M. LEESE: Weight standards. In: ENTWISTLE 2017

= C. S. Lightfoot: Byzantine weights and related material, 1998-2008, In: Amorium Reports. 3: The Lower City Enclosure. Finds Reports and Technical Studies. Eds: C. S. Lightfoot and E. A. Ivison. Istanbul 2012

= G. Manganaro: Exagia (pesi-campioni) tardo-romani e bizantini in Sicilia. Jahrbuch für Numismatik und Geldgeschichte 51/2 (2001/2) 57-82.

= F. MAnns: Quelques poids et pesons du Musée de la Flagellation. In: Studia Hierosolymitana in onore de Bellarmino Bagatti. 1: Studi archeologici. Jerusalem 1976, 81-109.

= J. R. Martindale: The Prosopography of the Later Roman Empire. III. Cambridge 1992.

= A. MiNČEV: Early Byzantine weights found in northeastern Bulgaria and some notes on their production, distribution and use. In: Numismatic, Sphragistic and Epigraphic Contributions to the History of the Black Sea Coast. International Coference (sic!) in Memory of Dr. Milko Mirchev Varna, September $15^{\text {th }}-17^{\text {th }}, 2005$. Acta Musei Varnaensis VII/2. Varna 2008, 7-40.

= J. Mitchell: 444. Peso bizantino da due once. In: C. Bertelli-G. P. Brogiolo: Il futuro dei Longobardi. L'Italia e la costruzione dell'Europa di Carlo Magno. Milan 2000, 461.

$=$ P. Monceaux: Un poids et des amulettes antiques, récemment trouvés en Tunisie. Bulletin de la Société Nationale des Antiquaires de France 1916, 340-341.

= U. MonNERET DE VILlard: Exagia bizantini in vetro. Rivista Italiana Numismatica 35 (1922) 93-107.

= Münz Zentrum: Münz Zentrum Auktion XXX. Kelten. Römische Münzen. Judaea. Byzanz ... Hotel Intercontinental...5000 Köln 1. Beginn: Montag, 21 November 1977, Köln.

= A. Papadopoulos-Kerameus: Catalogue descriptif des poids de antiques. l'École Evangélique ä Smyrne 3 (1880) 58-96.

= D. PAPAnikola-BAKIRTzi (ed.): Everyday Life in Byzantium - Byzantine Hours: Works and Days in Byzantium. Athen 2002.

= E. PERNICE: Griechische Gewichte. Berlin 1894. 
Petrie 1926

QEDAR 1978

QEDAR 1979

QEDAR 1981

QEDAR 1983

Ross 1962

SAGUì 1993

SCHILBACH 1970

STEFAN 1965

STIEGEMANN 2001

VLADIMIROVA-ALADJOVA 2001

STRZYGOWSKI 1904

TEKIN 2015

TeKIN-BARAN-ÇeliK 2013

TOBIAS 2015

VAN DOORNINCK 2002

VASILOPOULOU 1983

VIKAN

ZACOS-VEGLERY 1972
= W. M. F. PETRIE: Ancient Weights and Measures. London 1926

= S. QEDAR: Münz Zentrum Auktion XXXII. Gewichte aus drei Jahrtausenden. Köln 1978.

= S. QEDAR: Münz Zentrum Auktion XXXVII. Gewichte aus drei Jahrtausenden. Teil II. Köln 1979.

= S. QEDAR: Münz Zentrum Auktion XLV. Gewichte aus drei Jahrtausenden. Teil III. Köln 1981.

= S. QEDAR: Münz Zentrum Auktion XLIX. Gewichte aus drei Jahrtausenden. Teil IV. Köln 1983.

= M. C. Ross: Catalogue of the Byzantine and Early Medieval Antiquities in the Dumbarton Oaks Collection. 1: Metalwork, Ceramics, Glass, Glyptics, Painting. Washington D.C. 1962.

= L. SAGuì: Crypta Balbi (Roma): conclusione delle indagini archeologiche nell'esedra del monumento romano. Relazione preliminare. ArchMed 20 (1993) 409-418.

$=$ E. SCHILBACH: Byzantinische Metrologie. München 1970.

= G. STEFAN: Numele unui praefectus Urbi pe o inscriptie din Dobrogea din secolul al VI-lea e.n. [The name of an urban prefect of Constantinople on a sixth-century inscription from Dobruja]. In: Omagiu lui P. Constantinescu-Iasi: cu prilejul împlinirii a 70 de ani. Bucureşti 1965, 141-145.

$=$ C. StiegemanN (ed.): Byzanz - Das Licht aus dem Osten. Kult und Alltag im Byzantinischen Reich vom 4. bis 15. Jahrhundert. Katalog der Ausstellung im Erzbischöflichen Diözesanmuseum Paderborn 2001. Paderborn 2001.

= D. VLADIMIROVA-ALADJOVA: Новооткрита стьклена екзагия [A recently discovered glass exagia]. Нумизматика и сфрагистика/Numismatica e Sphragistika 8/1-2 (2001) 42-46.5

$=$ J. STRZYGOwski: Catalogue général des antiquités égyptiennes du Musée du Caire: Koptische Kunst. Vienna 1904.

$=$ O. Tekin: Corpus Ponderum Antiquorum et Islamicorum. Turkey. 3: Suna and Inan Kiraç Foundation Collection at the Pera Museum. 2: Late Roman and Byzantine Weights. Istanbul 2015.

$=$ O. Tekin-BARAN-Celik: Corpus Ponderum Antiquorum et Islamicorum. Turkey. 2: Istanbul Archaeological Museums. Greek, Roman, Byzantine and Islamic Weights in the Department of Metal Objects (Turkish Institute of Archaeology). Istanbul 2013.

$=$ B. ToBIAs: Glass weights. In: TeKIN 2015, pls 187-200.

= F. vAN DoORnINCK: The Byzantine ship at Serçe Limanı: an example of small-scale maritime commerce with Fatimid Syria in the early eleventh century. In: R. Macrides (ed.): Travel in the Byzantine World. Papers from the Thirty-fourth Spring Symposium of Byzantine Studies, Birmingham, April 2000. Aldershot 2002, 137-148.

$=$ V. VASILOPOULOU: Vizantina stathmia tou Nomismatikuo Mouseion Athénon [Byzantine weights in the Numismatic Museum of Athens]. Arhaiologiké Efémeris 122 (1983) 238-276.

$=$ G. VIKAN: Byzantine Objects of Everyday Life from the Menil Collection. Unpublished manuscript. = G. ZACos-A. VeGLery: Byzantine Lead Seals. Basel 1972. 